\title{
AS FORMAS DE REIVINDICAÇÃO E PROTESTO IDENTIFICADOS NOS MOVIMENTOS SOCIAIS VINCULADOS À PROBLEMÁTICA DO TERRITÓRIO
}

\author{
THE FORMS OF CLAIM AND PROTEST IDENTIFIED IN SOCIAL MOVEMENTS LINKED TO THE \\ TERRITORY PROBLEMATIC
}

Beatriz Maria Soares PONTES 1

Artigo recebido em 01/10/2018 e aceito em 12/12/2018

Palavras-chave: Movimento Social; Território; Governo Autônomo; Reivindicação; Protesto.

Keywords: Social Movement; Territory; Autonomous Government; Claim. Protest.

\begin{abstract}
R E S U M O
0 presente trabalho tem como objetivo, avaliar as formas de reivindicação e protesto identificados nos movimentos sociais, vinculados ao território. Em primeiro lugar, foi analisado a questão do Governo Autônomo das terras habitadas pelos Wampis, sediados na Amazônia peruana, em face do Governo do Peru que, de acordo com a Constituição daquele país, não aceita terras e governos autônomos, no âmbito do Estado peruano, tendo em vista a Constituição da referida nação. Em seguida, estudamos o movimento dos mineiros cooperados da região de Oruro, na Bolívia, bem como outras questões referentes à mineração, levadas a termo pela empresa estatal, além de outras estrangeiras. Na sequência, observamos a tentativa da implementação do Projeto ProSavana, em Moçambique e, o questionamento realizado pelos camponeses sobre o aludido projeto, as diferentes providências por eles tomadas e a vitória final deste movimento camponês. Finalmente, discutimos o problema, que ainda persiste na atualidade, sobre os nativos do arquipélago de Chagos, localizado no Oceano Índico, as atitudes assumidas pelo Governo inglês, os interesses norte-americanos, envolvendo a ilha Diego Garcia, ao sul do aludido arquipélago, por nela terem instalado uma base militar, considerada, pelos norte-americanos, de alto significado estratégico, além das petições efetivadas, junto a instituições internacionais, com o propósito de reverter a saída dos nativos do arquipélago em questão. No artigo em questão adotamos o conceito de Movimento Socioterritorial e seus desdobramentos sob a ótica dialética, com o respaldo de pesquisas bibliográficas, documentais, jurídicas e de campo (Moçambique). À guisa de conclusão são observadas as razões e o significado desses movimentos vinculados ao território.
\end{abstract}

\begin{abstract}
A B S T R A C T
The present work aims to evaluate the forms of protest identified in the social movements, linked to the territory. Firstly, the Autonomous Government issues of the lands inhabited by the Wampis, based in the Peruvian Amazon, were analyzed according to Peru's Government that, according to the Constitution of that country, does not accept lands and autonomous governments, within the scope of the Peruvian State, in view of the Constitution of that nation. Next, we study the cooperated miner's movement from the Oruro region of Bolivia, as well as other mining issues, carried out by the state company, as well as other foreign ones. In the sequence, we observed the attempt to implement the ProSavana Project in Mozambique and the peasants questionings about the project, the different measures taken by them and the final victory of this peasant
\end{abstract}

\footnotetext{
1 Profa. Dra. / Livre-Docente pela UNESP (2008). Profa. Titular aposentada da UFRN. Atualmente, é Professora Colaboradora do Grupo de Pesquisas Movimentos Sociais e Dinâmicas Espaciais (UFPE) e do Grupo de Pesquisas Geopolítica e Território, do Centro de Estudos em Geopolítica e Relações Internacionais (CENEGRI). Presentemente, está envolvida com pesquisas relativas à Geopolítica do Oriente Médio e do Extremo Oriente, com particular ênfase à China. E-mail: lavbiapontes@hotmail.com.
} 
movement. Finally, we discuss the persistent current problem of the natives of the Chagos archipelago located in the Indian Ocean, the attitudes assumed by the British government, the American interests, involving Diego Garcia's Island, south of the archipelago, for installing a military base, considered by the Americans, of high strategic significance, in addition to the petitions made, with the international institutions, with the purpose of reversing the natives' departure of it. In this article we adopted the Socioterritorial Movement concept and its unfolding under the dialectical order, supported by bibliographical, documentary, legal and field research (Mozambique). As a conclusion, the reasons and meaning of these movements linked to the territory are observed.

\section{INTRODUÇÃo}

Devemos ressaltar que ao longo dos movimentos aqui discutidos, podemos observar que a resistência social, muitas vezes, lutou pelo seu território, todavia, nem sempre conseguindo estabelecer-se no mesmo. Outras vezes, os atores sociais lutaram e lograram permanecer no território, por algum tempo. Em outros processos históricos, resistiram, com muito ardor e presenciaram a diminuição do seu território ou, como no caso dos africanos, lutaram, com vigor, contra os colonizadores, perdendo por um longo período, o seu território para, posteriormente, reavê-lo quando do advento das independências dos Estados Nacionais Africanos, ora por via pacífica, ora mediante guerras e conflitos de grande magnitude.

Em sua totalidade os movimentos são compreendidos como agentes criadores e recriadores de espaços e territórios. 0 movimento socioterritorial é um sujeito coletivo ou grupo social que se mobiliza para desenvolver uma determinada ação em defesa dos seus interesses, sobretudo, aqueles relativos ao território.

Deste modo, o estudo do fenômeno social, realizado sob um olhar geográfico, torna-se o estudo do fenômeno socioespacial e/ou socioterritorial (FERNANDES, 2005).

Portanto, é relevante que reforçemos que o espaço como fragmento ou fração é uma representação, construída a partir de uma determinação interagida pela receptividade, constituída por uma relação social.

Para evitar equívocos na compreensão do conceito de movimentos socioterritoriais é preciso que esclareçamos que o espaço social, ou seja, a dimensão social, está contida no espaço geográfico, criado originalmente pela natureza e transformado, continuamente, pelas relações sociais (SANTOS, 2008), que produzem diversos outros tipos de espaços materiais e imateriais, como por exemplo: políticos, culturais, econômicos e ciberespaços (FERNANDES, 2005, p. 26).

0 espaço é parte da realidade, portanto, multidimensional. Para uma eficaz análise conceitual é necessário definir o espaço como composicionalidade, ou seja, só pode ser compreendido em todas as dimensões que o compõem. Essa simultaneidade em movimento manifesta as propriedades do espaço em ser produto e produção, movimento e fixidez, processo e resultado, lugar de onde partimos e aonde chegamos. 
Assim, o espaço geográfico é formado pelos elementos da natureza, bem como pelas dimensões sociais produzidas pelas relações entre as pessoas, como cultura, política e a economia (FERNANDES, 2005, p. 26).

Um movimento socioterritorial é aquele que tem o território como trunfo, como motivo de sua existência, em que todas as suas ações têm como finalidade, a conquista de um território que pode ser uma casa ou um lote de assentamento. Temos os movimentos socioterritoriais urbanos que têm como objetivo a conquista da moradia e os movimentos socioterritoriais camponeses que lutam por acesso à terra.

No que tange aos movimentos socioterritoriais rurais, a luta pela terra é condição de acesso ao espaço da produção dos meios de existência e, a luta na terra, como forma mais ampla de manutenção ou melhoramento dessas condições (PEDON, 2009, p. 190).

Segundo Pedon (2009), destacam-se as ações intencionais projetadas no espaço e a sua transformação em território, revelando o conflito como consequência deste processo, que se materializa nas ocupações de terras e nas manifestações.

Por outro lado, o território do movimento socioterritorial pode ser tanto material, quanto imaterial, não havendo possibilidade de verificarmos o território material, sem o território imaterial, portanto, o território imaterial pode existir sem um território material. Todavia, para que o território material exista é condição inevitável, a existência de um território imaterial como, por exemplo, as ideologias (FERNANDES, 2009; CUBAS, 2009).

Do mesmo modo que alguns movimentos transformam espaços em territórios, estes também se territorializam e são desterritorializados e, se reterritorializam, resgatando consigo, suas identidades territoriais e territorialidades (FERNANDES, 2009). A produção do espaço acontece por intermédio das relações sociais, no movimento da vida, da natureza e da artificialidade, principalmente, no processo de construção do conhecimento. Assim, as relações sociais são, predominantemente, produtoras de espaços fragmentados, divididos, unos, singulares, dicotomizados, fracionados, portanto, também conflitivos (FERNANDES, 2005).

É importante ressaltarmos que o espaço como fragmento ou fração é uma representação, construída a partir de uma determinação interagida pela receptividade, constituída por uma relação social. Assim, o território é o espaço apropriado por uma determinada relação social que o produz e o mantém.

As primeiras reflexões a respeito do conceito de movimentos socioterritoriais datam da segunda metade da década de 1990. A produção ou a construção do espaço acontece pela ação política, pela intencionalidade dos sujeitos para transformação de suas realidades. Os espaços políticos são reproduzidos pelo movimento da ação, constituindo a espacialização (FERNANDES, 2005). 
Do mesmo modo que alguns movimentos transformam espaços em territórios, também se territorializam e, são desterritorializados e, se reterritorializam e, carregam consigo suas territorialidades, suas identidades territoriais, constituindo uma pluriterritorialidade.

A criação ou conquista de um território poderá ocorrer com a desterritorialização e com a reterritorialização. Os territórios se movimentam também pela conflitualidade. 0 território é espaço de vida e morte, de liberdade e de resistência, carregando em si sua identidade, que expressa sua territorialidade.

Portanto, a partir do momento que nos propomos a realizar uma análise geográfica dos movimentos sociais, além da preocupação com as formas, ações e relações, é fundamental compreendermos os territórios produzidos ou construídos por tais movimentos. Portanto, vários movimentos são, sobretudo, socioterritoriais.

Os movimentos socioterritoriais para atingirem seus objetivos constroem espaços políticos, espacializam-se e promovem espacialidades. A construção de um tipo de território significa, quase sempre, a destruição de um outro tipo de território, de modo que a maior parte dos movimentos socioterritoriais formam-se, a partir dos processos de territorialização e desterritorialização.

Existem movimentos socioterritoriais no campo, na cidade e na floresta. Assim, o movimento social e o movimento socioterritorial são um mesmo sujeito coletivo ou grupo social que se organiza para desenvolver uma determinada ação em defesa de seus interesses, em possíveis enfrentamentos e conflitos, tendo como objetivo a transformação da realidade.

O espaço, o território, o lugar, as relações sociais, as escalas das ações nos ajudam a compreender os tipos de movimentos socioterritoriais e seus processos geográficos (isolados, territorializados ou espacializados).

Os movimentos socioterritoriais têm o território não só como trunfo, mas este é essencial para sua existência. Os movimentos camponeses, os indígenas, as empresas, os sindicatos e os Estados podem se constituir em movimentos socioterritoriais, porque criam relações sociais para tratarem diretamente de seus interesses e, assim, produzem seus próprios territórios.

Elemento fundamental do território geográfico é a materialização da existência humana. Consideramos esses movimentos como isolados, não por estarem sem contato com outras instituições, mas sim, por atuarem num espaço geográfico restrito.

Os movimentos (socioterritoriais) territorializados são aqueles que atuam em diversas macrorregiões e, formam uma rede de relações com estratégias políticas que, promovem e fomentam a sua territorialização. Todos os movimentos territorializados começam como movimentos isolados. Estes ao se territorializarem e romperem com a escala local, se organizam em redes e ampliam suas ações e dimensionam seus espaços. 
Os espaços produzidos pelos movimentos socioterritoriais são diversos e são constituídos de acordo com as suas ações. Esses movimentos fazem-se nos espaços de socialização política e espaços de socialização propositiva, onde geram as práticas políticas de seu desenvolvimento.

0 conflito é fato presente nas ações dos movimentos socioterritoriais e, são promotores de desenvolvimento e, refluxo das políticas das instituições. A exclusão, a negociação e a ressocialização são condições que se realizam e, se superam por meio das ações dos movimentos, na construção de espaços e conquista de territórios (FERNANDES, 2005).

Além do que acima expusemos, torna-se imprescindível a ponderação em torno do significado de reivindicação. Portanto, reivindicar significa reclamar, tentar reaver algo e recuperar, reaver ou obter algum objetivo ou propósito, principalmente, de ordem coletiva.

Os estudiosos entendem que a reivindicação e o protesto são, como identitários, forjados na experiência de carências comuns, que não levam em consideração o outro com quem esses movimentos dialogam, em particular, os organismos estatais.

Portanto, depreendemos que o protesto é uma forma de manifestação democrática, pública ou reservada, que demonstra o descontentamento em relação a alguma coisa. As pessoas que protestam contra algo, normalmente, não estão de acordo ou satisfeitas com determinada atitude ou ação.

Um protesto é caracterizado pelo ato de protestar, ou seja, fazer uma reclamação em relação a algo, uma ação ou resultado de reclamar sobre alguma coisa. Os protestos podem ter inúmeros motivos, sejam de interesses pessoais ou coletivos, envolvendo um ou vários grupos sociais. Também podem se manifestar de diversos modos como caminhadas e marchas pelas ruas de uma cidade ou por outras áreas que podem ser até, as rurais.

As manifestações, protestos e demais formas de ação coletiva que têm lugar na América Latina, possuem como denominador comum, as agendas de reivindicações sociais. Em termos gerais, os cidadãos estão demandando mais às democracias, exigindo melhores níveis de participação, transparência, não discriminação e, maior acesso a direitos essenciais como a saúde, educação, territórios, meio ambiente, segurança e igualdade.

De igual maneira, a limitação do direito de participação e a consulta prévia com povos indígenas vêm produzindo mobilizações sociais de distinta magnitude e intensidade na região.

As manifestações e protestos sociais nos países da América Latina se mantiveram constantes, durante as últimas décadas, assim como as respostas dadas por parte dos Estados a este fenômeno. 0 uso da força de forma desproporcional e, não focalizada, a realização de ações destinadas a desincentivar a participação cidadã ou a criminalização dos protestos sociais e dos defensores e defensoras de direitos humanos, formam parte dos meios que os Estados utilizam para desarticular os movimentos sociais. 
Em razão do exposto, para cumprir com as obrigações internacionais de respeito e proteção dos direitos envolvidos nestas manifestações, é transcendental que, em primeiro lugar, exista um entorno propício e seguro para que a população, que inclui a sociedade civil e os defensores e defensoras de direitos humanos, possam exercer livremente os direitos implicados. Em seguida, é essencial que, sob estas mesmas circunstâncias, reconheçamos o direito de todas as pessoas a observar e monitorar as reuniões e manifestações coletivas. Igualmente, que o poder público aja, conforme protocolos de atuação no marco de protestos ou manifestações compatíveis com as obrigações contraídas, em matéria de direitos humanos e, por último, que tais regulamentações sejam cumpridas na prática.

No artigo em questão adotamos o conceito de Movimento Socioterritorial e seus desdobramentos sob a ótica dialética, com o respaldo de pesquisas bibliográficas, documentais, jurídicas e de campo (Moçambique).

O texto a seguir foi estruturado da seguinte forma: Peru: O Movimento Social Wampis, na Amazônia Peruana; O Movimento Social dos Mineiros Cooperados, na Bolívia; O Movimento Social dos Camponeses Moçambicanos Face ao Projeto ProSavana e o Movimento Social dos Nativos do Arquipélago de Chagos (Oceano Índico), bem como as conclusões.

\section{PERU: O MOVIMENTO SOCIAL WAMPIS, NA AMAZÔNIA PERUANA}

As populações indígenas defendem sua autonomia por meio da ideia de um Estado plurinacional. Essa noção já se encontra estabelecida nas Constituições da Bolívia e do Equador.

La Poza é uma pequena aldeia que se situa nas terras Wampis, na qual vivem cerca de 10 mil pessoas, entre eles: caçadores, pescadores, horticultores, bem como professores e enfermeiros, agrupados em pequenas aldeias ou comunidades. Esta área localiza-se no extremo norte da Amazônia peruana, mais exatamente, nos Departamentos do Amazonas e de Loreto.

Salientamos que o Governo Autônomo Wampis resultou de um processo que teve início na década de 1990. Na formação deste Governo Autônomo participaram antropólogos, juristas e geógrafos próximos dos indígenas. Após o mapeamento deste território e dos seus recursos, os Wampis estabeleceram órgãos de Governo, além de um arcabouço legal próprio. Mediante o estabelecimento das providências acima destacadas, muitos líderes anunciaram, no final de 2015, a criação da Nação Wampis, exigindo, na oportunidade, a gestão independente dos recursos naturais, sobretudo, aqueles cobiçados pelo setor privado.

Todavia, no presente, o esforço dos Wampis permanece sem resposta, uma vez que a Legislação peruana não reconhece entidades como nações ou governos indígenas. Para a 
administração peruana, só são reconhecidas as comunidades ameríndias, as quais só se remetem a subconjuntos territoriais e demográficos limitados.

O Estado peruano não se defronta, apenas, com a reivindicação do Governo Autônomo Wampis, mas, enfrenta, contemporaneamente, tensões recentes com os vizinhos Wampis, havendo, portanto, a necessidade de atuar com cautela.

Por outro lado, o líder da comunidade procura deixar bem claro que em La Poza, as pessoas são contra a mineração ilegal porque polui os rios. Entretanto, não é menos verdade, que alguns cartazes locais assinalem a compra e venda de ouro, denotando que a exploração aurífera, ainda se faz sentir naquela localidade.

Além disso, na localidade de Puerto Galilea, que apresenta uma rua simples, denominada Calle de la Amistad, é o marco que separa as duas aldeias. A situação observada nas aldeias denota a tensão que envolve os Wampis e os chamados colonos, dedicados as atividades auríferas. Nesta localidade, ocorreu uma reunião, cujo tema dizia respeito ao destino reservado aos colonos, acusados de estarem envolvidos na atividade mineradora ilegal.

Antes de entrarmos no mérito mais profundo da questão que hora pesquisamos, faz-se mister uma referência ao Governo Autônomo Wampis, o qual surgiu quando as pressões ambientais se tornaram mais acentuadas, enquanto o Estado peruano, apresentava uma postura mais passiva.

Em 2015, uma delegação de chefes Wampis percorreu várias comunidades, ao longo dos rios Santiago e Morona, procurando convencer seus membros a aderir ao projeto de Governo Territorial Autônomo, que seria incorporado ao Território Integral da Nação Wampis.

Convém esclarecermos que o conceito de Território Integral procede de uma reflexão conduzida em 1990, por organizações indígenas no noroeste da Amazônia peruana, apoiadas por advogados e antropólogos. 0 propósito visava sair do modelo comunal para uma unidade territorial maior. Os Wampis tinham, para a concretização deste território autônomo, o argumento ecológico, porquanto os metais pesados liberados nos solos e rios, por mineradores de ouro ou em razão de rompimentos no oleoduto norte-peruano, ameaçavam a fauna, a flora e a saúde do conjunto da população.

Em 2016, foram identificados onze rompimentos de oleoduto que causaram uma poluição alarmante nessa região da Floresta Amazônica. Além disso, o comércio de madeira, em grande escala ou a sobrepesca, foram denunciados como uma ameaça à biodiversidade e ao bem-estar da população. Assim, a integração de áreas comunais dentro de uma jurisdição comum foi apresentada como a única solução para preservar o território ancestral, diante da indústria extrativa e da poluição por ela acarretada. Portanto, a criação de um governo autônomo seria uma estratégia de defesa territorial, sendo uma resposta aos esforços feitos para a divisão dos Wampis em comunidades. Depreendemos que o fato de cada comunidade ser levada a negociar caso a caso e, apenas, em seu nome, com as empresas, constituiu uma ferramenta de divisão, contra a qual os Wampis pretendiam lutar. 
Seria, também, uma questão de encontrar certa fluidez territorial que rompesse com a rigidez dos cadastros comunais e, que correspondesse mais ao habitat, tradicionalmente móvel e disperso, outrora privilegiado nessa parte da Amazônia, ou seja, relação com o território integral. Isto significaria, a recuperação da gestão do conjunto do território Wampis, ou seja, a floresta, os rios, o ar e o subsolo. Compreendemos, então, que para os Wampis, o território é um todo e a sua cultura está baseada em todos esses elementos.

Observamos que, para um analista mais atento, os Wampis, contemporaneamente, estavam mais ligados à Convenção 169, da Organização Internacional do Trabalho sobre Povos Indígenas e Tribais (1989) e a Declaração das Nações Unidas sobre os Direitos dos Povos Indígenas (2007). Os referidos Tratados colaboraram, justificando a legitimação, na esfera internacional, do direito à autodeterminação, à autonomia territorial, política e administrativa, nos Estados-Nações contemporâneos. Os Wampis encontraram neles um apoio poderoso para seu esforço, não apenas, por se tratar do desenvolvimento de um modelo transparente de Governo, mas também, mediante a forma como esses Tratados conceituavam o tema da Lei. Sabemos que os Estados são levados a reconhecer a preexistência de nações ou povos autóctones. Por essa razão, os Wampis se referiram constantemente a isso, com o intuito de lembrar ao Estado peruano suas obrigações, já que ele é signatário desses Tratados.

Assim sendo, a autonomia na qual se baseia o povo Wampis, não está lastreada em ambições independentistas, mas, ajuda a explicar-nos a condição de peruanos dos Wampis, evidenciando que o propósito dos mesmos, não se refere ao rompimento do seu relacionamento com o Estado, mas, a pretensão deles mesmos de administrarem o próprio território, de acordo com a visão e a cultura, das quais são detentores, visando à preservação do meio ambiente.

Na verdade, o objetivo maior dos Wampis é contribuir para o desenvolvimento do País, por meio de um uso racional e sustentável dos recursos. Fica muito claro, por conseguinte, que o Governo Autônomo, deve ser visto como um instrumento que permitirá lembrar ao Estado, que a nação Wampis existia antes da República do Peru e, que este Estado, deverá aplicar os textos que ele mesmo ratificou.

Todavia, em Lima, o contexto Wampis acima consignado, não é visto como enxerga o aludido povo indígena. Devemos ressaltar que, alguns altos funcionários e deputados, acusam o Governo Autônomo Wampis de ameaçar a soberania do Estado peruano, sobretudo, em face do estreito vínculo existente entre os Wampis e os Shuar do Equador, isto é, uma relação de parentesco à qual somam-se as trocas comerciais, além de várias parcerias políticas e logísticas entre federações indígenas.

Nesse contexto, a autonomia Wampis enfraqueceria sua soberania na região, já marcada por uma longa história de conflitos fronteiriços, ocorridos entre o Peru e o Equador, que disputaram a fronteira por mais de um século, até 1993 e, isto significaria, sob a ótica dos altos funcionários e deputados, um 
primeiro passo para a reivindicação da independência. Para outras autoridades, essa acusação de separatismo, sem fundamento, destinar-se-ia, apenas, ao descrédito da iniciativa.

$\mathrm{Na}$ verdade, constatamos que a presidência da Comissão Ordinária dos Povos Andinos, Amazônicos e Afro-Peruanos, Meio Ambiente e Ecologia, distinguiu o Governo Wampis, outorgandolhe o título de defensor do meio ambiente".

Apesar das posições diferenciadas, as reuniões envolvendo o povo Wampis prosseguiram, centrando as discussões, no que concerne às sanções contra os garimpeiros atuantes naquele território. Nessas reuniões, se fazem presentes as várias instâncias do Governo, descritas nos estatutos constitutivos do Governo Autônomo. A discussão tem prosseguido, no âmbito de tais reuniões, resgatando, sobretudo, o crescente apego dos Wampis a uma organização de tipo estatal, um governo e uma assembleia, organização que lhes era estranha, até a segunda metade do século XX.

A referida escolha é devida a razões estratégicas. A primeira delas consiste em fazer parte da continuidade do modelo de comunidade. De fato, essa continua sendo a estrutura política básica, na qual esse novo governo se apoia. As assembleias comunais elegem os membros da Grande Assembleia. A ideia não é tanto desfazer as ferramentas legais atuais, mas, integrá-las em uma nova dinâmica político-territorial.

Em seguida, trata-se de utilizar as mesmas ferramentas que o Estado peruano, assumindo algumas de suas prerrogativas, de modo a dialogar com o Estado e se impor como força democrática. A Grande Assembleia elege, assim, o presidente do Governo Autônomo, que nomeia os membros de seu "conselho de diretores". Cada um destes últimos, administra uma área específica: educação, saúde, passando pelo orçamento, meio ambiente, transportes e comércio. Como podemos aferir, seria uma forma de tentar uma interface com o Estado central.

O esforço autonomista dos Wampis representaria outro caminho político? Alguns dirão que ele não é, de forma alguma, incompatível com o neoliberalismo circundante, uma vez que a Constituição de 1993 colocou o Peru no caminho de uma economia desregulamentada, reconhecendo, pela primeira vez, a pluralidade étnica do país e a obrigação do Estado de protegê-la (Artigo 2.19). No Peru, como nos outros países da América Latina, o multiculturalismo neoliberal visa valorizar as especificidades socioculturais das minorias indígenas, a fim de melhor integrá-las à economia de mercado.

Procuramos ouvir o titular da Prefeitura do Distrito de Rio Santiago, que abrange a metade ocidental de todo o território sobre os eixos de sua política, bem como a sua postura em face do desenvolvimento. Observamos, então, que o seu pensamento não é muito diferente do que acima, já foi exposto e, por nós, discutido. Por outro lado, nas reuniões acima citadas, constatamos a presença de líderes de outros grupos indígenas, como, por exemplo, o Awajún, chefe do outro grande grupo étnico, residente nesta mesma região. 
O líder acima ressaltado, considera-se favorável à iniciativa do povo Wampis e, reconhece semelhanças com sua política municipal. Mas, identificamos um ponto de desacordo fundamental que o opõe ao Governo Autônomo, o qual diz respeito à sua gestão econômica do território, incluindo, a questão da propriedade privada.

De fato, se os estatutos constitutivos da nação Wampis procuram reafirmar o caráter coletivo e inalienável da propriedade territorial, o Awajún (líder) defende uma visão oposta, isto é, na sua forma de pensar, adquirir um terreno na comunidade garantiria a ele os seus direitos de propriedade? Será que poderão tirá-lo de lá a qualquer momento? Desta forma, quem poderá garantir a este líder, se não lhe for dada uma garantia de que a terra dele, verdadeiramente, lhe pertence?

Segundo ele, não é porque sendo um indígena, deverá viver na pobreza. Notamos que ele lamenta a perspectiva muito fechada da Assembleia do Governo Territorial Autônomo da Nação Wampis (GTANW), que recusa qualquer liberalização da terra e, deseja conferir à escala do território Wampis, o mesmo tipo de gestão coletiva, que a aplicada aos territórios comunais.

Nas comunidades, todas as decisões relativas à chegada de um novo morador, pressupõe a concessão de uma parcela para a construção de uma casa ou ao estabelecimento de uma empresa, as quais devem ser objeto de um acordo coletivo por votação. Em último caso, dependerá, portanto, da decisão da Assembleia do Governo Territorial Autônomo da Nação Wampis (GTANW) e de sua Assembleia.

Segundo alguns, o Awajún (líder), de acordo com o seu pensamento, precedentemente exposto, retransmite uma falácia comum, na qual a propriedade coletiva, legal, mas, informal, retardaria o desenvolvimento econômico, com os potenciais investidores, temendo que seus bens fossem confiscados arbitrariamente.

Ele trabalha em estreita colaboração com uma instituição responsável pela formalização da propriedade informal, o Organismo de Formalização da Propriedade Informal (COFOPRI). Muito ativa nas comunidades da Amazônia, ela incentiva os moradores das comunidades a recomprar a porção de terra em que sua casa foi construída. Apesar das boas intenções apresentadas, essa estratégia deixa poucas dúvidas sobre o objetivo dos poderes públicos: desmontar, gradualmente, o regime de comunidades, favorecendo o parcelamento progressivo dos seus territórios.

Além de se opor a qualquer exploração de petróleo, a forma como o Governo Wampis planeja administrar, coletivamente o acesso à terra, vai contra a orientação neoliberal do Governo peruano. A política econômica esteve, precisamente, no centro das discussões da Quinta Cúpula da Nação Wampis, realizada em agosto de 2017, na comunidade de San Juan de Morona. Os representantes eleitos da Grande Assembleia discutiram, ali, atividades alternativas e, não poluidoras, como o turismo ecológico, a piscicultura, a avicultura e a cultura do cacau.

Essa perspectiva faz parte de um modelo de desenvolvimento alinhado com os valores do bem viver. Essa noção, de que os líderes Wampis e as ONGs locais se apropriaram das terras, tornou-se a 
razão fundamental de muitas lutas indígenas na América Latina, especialmente, desde sua inscrição nas Constituições do Equador (2008) e da Bolívia (2009).

Além das orientações econômicas e políticas, os valores do bem viver incluem uma exigência democrática. De acordo com os Estatutos do Governo Autônomo, a autoridade suprema é a Grande Assembleia, um colégio de dirigentes. Durante as reuniões, os líderes evitam, cuidadosamente, monopolizar a palavra, que é mais protagonizada pelos representantes comunitários, que mais fazem reivindicações e se esforçam para que a prevalência da voz de sua comunidade seja ouvida. Assim, cada um deles, expõe o seu ponto de vista, tentando convencer a plateia presente de que sua legitimidade emana de uma base local, ou seja, a das comunidades.

Portanto, a afirmação da anterioridade da Nação Wampis, em relação à chegada dos colonizadores espanhóis, demanda a reivindicação de um diálogo, de igual para igual, com o Estado central e a promoção de uma política de desenvolvimento, de acordo com os valores do bem viver: o Governo Autônomo reúne todos os elementos que levaram a Bolívia e o Equador a se definirem, constitucionalmente, como Estados plurinacionais.

Ao contrário do multiculturalismo, o plurinacionalismo, vai além da atribuição aos povos indígenas de um status de minoridade, que deve ser integrado a uma sociedade majoritária. Sem renunciar a um princípio de unidade nacional, trata-se de estabelecer uma relação mais horizontal entre o Estado e as entidades que o compõem, com cada uma podendo reivindicar uma gestão autônoma do seu território e de seus recursos. Isso implica uma profunda reforma do aparelho legislativo. Os que governam o Estado peruano aceitariam esta proposta?

Quando, em novembro de 2015, quase trezentos líderes Wampis, representando cerca de setenta comunidades, formalizaram a criação de seu Governo Autônomo, o esforço era certamente sem precedentes, mas, inscrevia-se numa longa e delicada história da relação entre os indígenas e o Estado peruano. A iniciativa se apresentou, de início, como uma reação à chamada Lei das Comunidades Nativas, adotada em 1974, pelo Governo Militar de Juan Velasco Alvarado. Líder autoritário de orientação esquerdista, Velasco decretou uma ampla reforma agrária, voltada para a redistribuição das terras aráveis, salientando-se que muitas foram monopolizadas por grandes latifundiários.

A Lei das Comunidades Nativas foi o primeiro corpus legal a garantir os direitos territoriais aos indígenas da Amazônia. Ela encorajou as várias etnias a se unirem nas comunidades, cujos membros, coletivamente, proprietários do território, desfrutariam de certa autonomia na administração dos assuntos internos. A Lei deveria garantir a inalienabilidade das terras comunais.

Símbolo de emancipação, após ondas coloniais de grande violência, esse dispositivo permaneceu, no entanto, projetado para integrar as populações amazônicas (1,05\% da população total atual do Peru) na dinâmica nacional. A inclusão de comunidades em uma complexa rede administrativa e a eleição de representantes encarregados de representar, localmente, o Estado, cuja 
comunidade é, em última análise, apenas uma espécie de excrescência, são todas formas de estabelecer a legitimidade das instituições públicas na vida cotidiana.

Além disso, o Estado central, continua sendo o dono da água, da fauna e do subsolo, significando que o mesmo cede para uso o solo e os recursos florestais para as comunidades. Portanto, o Estado reserva-se o direito de conceder parcelas a empresas extrativas, como as companhias petrolíferas, apesar dos riscos e consequências de suas atividades para o ambiente e a saúde da população.

O gradual estabelecimento do Estado nessa região só revelou o lugar que ocupa desde os primórdios da colonização, isto é, o de um espaço considerado vazio, cuja exploração é guindada à condição de causa nacional. Depreendemos, então que, a criação das comunidades foi, em última instância, muito problemática porque, legalmente, os recursos continuam a pertencer ao Estado, que pode decidir explorar a floresta ou o petróleo, no interior dos territórios comunais, porque é responsável pelo desenvolvimento político e administrativo interno.

O exemplo mais recente é o da atribuição à Petroperú, empresa estatal, com o direito de exploração de trinta anos sobre o lote de petróleo número 192, que cobre 500 mil hectares, no norte da Amazônia e, tem capacidade de produção de 10 mil barris por dia. 0 anúncio acarretou o protesto de centenas de comunidades tradicionais, diretamente, afetadas por essas atividades.

Limitado desde o início, esse direito à propriedade coletiva foi, em seguida, atacado o tempo todo por sucessivos governos. A natureza inalienável do território comunal foi revogada pela Constituição de 1993, abrindo o caminho para a privatização das parcelas comunais. A liberalização da terra começou em 1991, com o objetivo de por fim ao paternalismo estatal, em relação às comunidades rurais, estimulando o investimento privado que vê na propriedade coletiva um arcaísmo précapitalista.

0 processo de liberalização se aprofundou nos anos 2000, tendo em vista a indústria de petróleo e gás, ligada à forte demanda internacional. Como resultado, as atividades relacionadas ao petróleo e à extração mineral, representaram 14,36\% do PIB peruano, em 2016. A importância desse setor foi incentivada pelo aumento do preço do barril de petróleo, especialmente, a partir de 2005. Durante seu segundo mandato (2006-2011), o presidente Alan García, tentou remover os obstáculos ao investimento privado, com uma política fiscal vantajosa e a licitação maciça de áreas de exploração. Enquanto em 2005, os lotes de petróleo cobriam apenas 15\% da Amazônia peruana, cinco anos depois, cobriam 490 mil quilômetros quadrados, ou quase, 72\% do território das terras amazônicas. Essas decisões políticas provocaram fortes protestos das federações indígenas, violentamente reprimidas pela Polícia. Infelizmente, os confrontos em Bagua, em junho de 2009, deixaram 33 mortos e mais de duzentos feridos. 


\section{O MOVIMENTO SOCIAL DOS MINEIROS COOPERADOS, NA BOLÍVIA}

Nas minas de San José, em Oruro, na Bolívia, comprovamos a existência de alguns minerais, entre os quais, prata, estanho, zinco e chumbo. Essa atividade mineral é realizada por cooperativas que dividem, entre si, os veios existentes nas maiores jazidas de metais preciosos da Bolívia.

A respeito das minas acima referidas, devemos salientar os confrontos que ali tiveram lugar, em 2016, quando ocorreram confrontos com o Governo boliviano, nos quais foram comprovadas atitudes violentas perpetradas por ambos os lados em contenda.

Em agosto de 2016, os associados que integravam as cooperativas bloquearam eixos logísticos e estratégicos no território boliviano. Os confrontos entre os cooperados e a polícia resultaram em mortes, além de dezenas de feridos, culminando com a tragédia que se tornou realidade, mediante o sequestro e o assassinato, do Vice-Ministro do Interior, que estivera tentando negociar com a ala reivindicante dos mineiros de Oruro. 0 Estado boliviano, através do seu titular, considerou este evento imperdoável e, em seguida, decretou luto oficial nacional.

Em face dessa violência, teve lugar uma revisão da Lei das Cooperativas, permitindo aos trabalhadores do setor, a oportunidade de se sindicalizarem livremente. Temos que considerar, também, em Potosí, o grande centro de mineração da Bolívia, dominado pela Cerro Rico, ou seja, a montanha de prata, com 4.800 metros de altura. Nesta área, o mineiro pode trabalhar como terceirizado, assinando contratos por preço fixo, por tarefa ou por dia. Nesta mina, a atividade extrativa mineral é norteada por um duro trabalho cotidiano e, não raro, verificamos a perda de vidas humanas.

As cooperativas existentes nessas áreas são, assim, organizadas: os lucros não são distribuídos e os grupos privilegiados exploram o trabalho dos outros, com jornadas de trabalho que, às vezes, ultrapassam dezesseis horas. Por essas razões, os mineiros se opõem ao processo de sindicalização.

Entretanto, salientamos que já faz tempo que o presidente da Bolívia considerava os mineiros cooperativistas como aliados naturais e incondicionais do seu Governo. Isto significaria, portanto, que à época, tanto o Estado boliviano, quanto os mineiros, estiveram na vanguarda do processo de mudança e da luta contra o neoliberalismo dos anos 2000. Cumpre que destaquemos que, com mais de 130 mil trabalhadores, essa organização forma um forte contingente eleitoral, ainda mais importante, pelo fato de cada mineiro, geralmente, mobilizar os votos de sua família.

A partir de 2005, os mineiros cooperativistas apoiaram o Movimento para o Socialismo (MAS), o partido de Morales, presidente da Bolívia. À guisa de compensação, os mineiros mantinham postoschave nas administrações e nos ministérios. Em 2006, o ministro das Minas, era originário da Fencomin e, vários deputados, procediam de suas fileiras, os quais se beneficiaram de, pelo menos, 
nove medidas legislativas, desde a vitória de Morales, incluindo a Lei de Mineração, a qual colocava os seus direitos, acima dos de outros atores econômicos do País.

Todavia, em 2016, a Federação mostrou uma nova lista de queixas. Além do cancelamento da modificação da Lei das Cooperativas, ela aventava a possibilidade de se associar às empresas privadas, a fim de que estas últimas garantissem a exploração de suas concessões, bem como o relaxamento de normas ambientais que eram consideradas muito restritivas.

De acordo com a política do Movimento para o Socialismo (MAS), foi encaminhada uma proposta diferente daquela feita pelo Governo, antes da eclosão do supracitado conflito. 0 objetivo seria, ou operar como empresas e pagarem impostos, ou adotar o status de cooperativas, renunciando a cessão de suas concessões ou alugá-las a particulares.

Essa reivindicação sugeriu a seguinte questão: por que atacar essa importante força, uma das partes interessadas nos movimentos sociais que apoiam Morales? Talvez, o fato teria sua justificativa, em face da queda do preço das matérias-primas, que prejudicou as finanças públicas, obrigando o Estado a procurar novas receitas, sobretudo, alargando a base do imposto da mineração.

Devemos ressaltar que havia pessoas integrantes da sociedade boliviana que consideravam que os mineiros cooperativistas faziam o que queriam porque eram aliados do Governo, uma vez que todos pagavam os impostos devidos, à exceção dos mineiros.

Por outro lado, o Governo boliviano fora vitorioso, em relação aos setores com os quais tinha conflitos, acarretando maior fragilidade da oposição. Portanto, o Governo sentiu-se fortemente alicerçado, fazendo com que os mineiros se submetessem e admitissem os reclamos do Governo boliviano.

Entretanto, a tensão já remontava à própria origem dessa aliança discutível, entre um poder em busca do socialismo do século XXI e, um setor menos sensível à urgência da luta pela emancipação. Sem dúvida, os cooperativistas, ao que tudo indicava, pareciam ter se beneficiado de sua proximidade com o poder, visando à promoção de um capitalismo selvagem, mediante a adoção de um modelo neoliberal que recusava qualquer mediação do Estado.

Assim, a partir de 2006 e, com a chegada do MAS ao poder, mineiros cooperativistas e mineiros empregados pela Corporación Minera de Bolivia (Comibol), empresa estatal, se enfrentaram pelo controle dos veios em Huanuni, uma mina pública do Cerro Posokoni, no Departamento de Oruro. Seis anos após este fato, eles ainda exigiam concessões na mina de Colquiri. Ocorreram, ainda, novos confrontos em 2014 e a Lei de Mineração, que integra grande parte de suas demandas, foi adotada após três anos de elaboração e de negociações pontuadas por graves conflitos entre governo, mineiros cooperativistas e mineiros assalariados.

Após os acontecimentos de 2016, cinco Decretos, seguidos de Leis, fortaleceram o controle sobre as cooperativas. Eles previam o retorno ao Estado de concessões não exploradas ou cedidas a 
empresas privadas, isto é, uma vitória para o Governo, ainda que isso comprometesse o relacionamento do Governo com o antigo aliado.

Nesse contexto, observamos que os cooperativistas poderão realizar novos atos de violência, ameaçando retomar as manifestações se os prisioneiros envolvidos com o assassinato do ViceMinistro do Interior, não forem libertados.

Convém que esclareçamos que, segundo a Lei boliviana, as cooperativas são associações sem fins lucrativos, impulsionadas pelo trabalho solidário (Código das Cooperativas). Elas são um dos três atores envolvidos na produção mineral no País, ao lado da estatal Comibol e, de empresas privadas nacionais e transnacionais.

É importante, também, ressaltar que as cooperativas de mineração já existiam desde a década de 1960, porém, o seu número ampliou-se a partir de 1985.

Faz-se mister salientar, todavia, que o setor da mineração logrou experimentar um forte crescimento, à medida que os preços das matérias-primas foram aumentando, a partir de 2002.

Essas cooperativas, porém, contemporaneamente, respondem por apenas 19,5\% do total da produção, tendo em vista os trabalhos realizados em veios pobres, de baixa mecanização e de uma atividade, em grande parte artesanal, em comparação com 74\% das minas privadas e 6,5\% das minas estatais. Consideradas unidades sociais, elas estão isentas dos principais impostos de mineração e, pagam uma taxa reduzida de $2,5 \%$ pela venda de minérios, enquanto a taxa é de $8,5 \%$ para as empresas estatais e privadas.

Pelo que podemos depreender da análise dos confrontos sociais, por conta da atividade mineradora, a desigualdade social continua persistindo na Bolívia, com a exploração dos melhores dotados financeiramente, em relação àqueles que representam os segmentos carentes e trabalhadores da sociedade.

\section{MOVIMENTO SOCIAL DOS CAMPONESES MOÇAMBICANOS FACE AO PROJETO PROSAVANA}

Discutiremos, a seguir, o projeto ProSavana, que une o Japão e o Brasil a Moçambique.

Assim, Nakarari, aldeia do Distrito de Mutuali, muito distante de Maputo, em Moçambique, apresenta moradores que discutem o aludido Projeto e resolveram dizer não ao advento do mesmo, em terras moçambicanas. As organizações camponesas dos povoados vizinhos a esta aldeia ponderam que o Governo está diante de um impasse, porquanto a luta de tais camponeses logrou obter uma primeira vitória histórica, impedindo a pilhagem das suas terras com a reafirmação de que as mesmas a eles pertencem e, são por eles, cultivadas há muito tempo.

Os camponeses, também, consideram que a sua posição é decorrente da sua própria unidade, conotando que a sua união deverá ter continuidade. Portanto, a mobilização popular, cujo centro 
principal é Nakarari, assinalou o seu anseio de que o Projeto ProSavana não tenha guarida nas suas terras.

Resultado de uma cooperação triangular entre o Governo de Moçambique, a Agência Japonesa de Cooperação Internacional (Jica, em inglês) e a Agência Brasileira de Cooperação (ABC - órgão do Ministério das Relações Exteriores), o ProSavana visava introduzir explorações agrícolas comerciais no corredor de Nacala, uma região que compreende três Províncias e dezenove Distritos, no norte de Moçambique.

Com uma superfície de 14 milhões de hectares, a zona pretendida é considerada propícia às culturas de exportação (soja, algodão e milho) destinadas ao mercado mundial. O Porto de Nacala, no Oceano Índico, ligado à região por ferrovia, oferece vias de escoamento das mercadorias para a China.

O ProSavana se inscreve na pretensão por terras agrícolas que, desde 2008, devasta o Hemisfério Sul, particularmente, a África Subsaariana. Desde a crise mundial de alimentos que ampliou, significativamente, o preço dos produtos básicos, a aquisição de áreas para a produção, em grande escala, chamou a atenção dos investidores sequiosos de rendimentos fáceis.

Neste setor, são investidores os grupos alimentícios, bem como atores procedentes das altas finanças: corretoras, fundos especulativos, fundos de investimento de todas as espécies, operados por indivíduos que trabalhavam, até então, para bancos comerciais, tais como Goldman Sachs, Merrill Lynch e outros.

Da Etiópia à República Democrática do Congo, do Senegal ao Sudão, centenas de milhões de hectares foram vendidos, não para produções destinadas ao mercado interno, mas, para o mercado externo, mais rentável. O ProSavana reduz a terra a um simples bem mercantil, não levando em conta sua importância para os pequenos produtores rurais.

Neste quadro de referência, Moçambique se impôs como um destino muito importante nesta corrida eivada de equívocos. Em 2010, por ocasião de uma conferência internacional, em Riad, na Arábia Saudita, o ministro da Agricultura de Moçambique, colocou, nesta reunião, o seu país na condição de liberador das terras, oferecendo contratos de cinquenta anos, pelo preço de US\$ 1 por hectare, ressaltando, na ocasião, que esse preço estava ligado à ideia do desenvolvimento compartilhado.

Por trás da modernidade de uma cooperação Sul-Sul a serviço do desenvolvimento, o ProSavana alterava as relações de produção no campo, transformava os pequenos camponeses em trabalhadores, com contrato por tempo determinado ou indeterminado das grandes empresas e, pretendia fazer de Moçambique, uma plataforma central de produtos agroindustriais a serem exportados para o mundo inteiro.

Concebido em 2009, na cúpula do G8, em L’Aquila, Itália, durante as reuniões privadas entre o então primeiro-ministro japonês e o presidente brasileiro, à época, o Sr. Lula da Silva, o Projeto 
pretendia reproduzir a seguinte experiência: a da transformação, entre os anos 1970 e 1990, da savana tropical úmida de Mato Grosso, na principal região produtora de soja do planeta. Assim, a cooperação triangular do ProSavana tinha como objetivo desenvolver o norte de Moçambique, com o advento de tecnologias brasileiras, confiando às empresas japonesas, a comercialização dos produtos, principalmente, nos mercados asiáticos.

Nos bastidores da chamada parceria inovadora, atuava a GV Agro, uma empresa de consultoria ligada à Fundação Getúlio Vargas. À GV Agro é devido, ainda, o plano diretor do ProSavana e seu mecanismo de financiamento. Lançado com um investimento inicial de US\$ 38 milhões, pelos governos brasileiro e japonês, o Projeto deveria ser sustentado por um fundo ad hoc, atraindo US\$ 2 bilhões de investimentos privados.

O objetivo declarado do fundo era gerar rendimentos a longo prazo para seus investidores, estimulando o desenvolvimento econômico local e regional. Por outro lado, Maputo e Tóquio criaram um Fundo para a Iniciativa de Desenvolvimento ProSavana, a fim de sustentar diferentes modelos de integração de pequenos agricultores.

Os camponeses de Moçambique ouviram falar, pela primeira vez do ProSavana, através de uma entrevista, então, concedida pelo Ministro da Agricultura do seu País, a um jornal do Brasil. Tal fato preocupou os camponeses, uma vez que o Governo do seu País, até aquela data, não os havia informado a respeito do aludido projeto. Por seu turno, os camponeses ficaram interessados pelo que fora dito na entrevista e, pesquisaram, inteirando-se de que se tratava de um programa de infraestrutura, visando abrir o seu País às multinacionais do agronegócio. Observaram, também os camponeses, que empresários brasileiros declararam-se interessados, em relação à ideia de emigrar para o país africano, onde ser-lhe-ia prometida a concessão de terras por preços, sumamente, acessíveis.

O discurso da GV Agro, uma vez analisado, não fez jus à realidade, uma vez que o corredor de Nacala era muito diferente do bioma do Cerrado.

Embora os dois territórios se encontrassem na mesma latitude, a zona circunscrita pelo ProSavana era muito mais fértil e, portanto, mais importante para o campesinato local, do que seu suposto equivalente brasileiro. E, sobretudo, ao contrário de Mato Grosso, que na década de 1970, não era muito povoado, ela era habitada por 5 milhões de pessoas, em sua maioria, pequenos agricultores que produziam boa parte dos alimentos consumidos no País.

Em Moçambique, como em muitos outros países da África, a terra pertence ao Estado e não pode ser vendida. Essa prerrogativa, conferida em 1975, pela independência de Moçambique é garantida pela Constituição de 1990. De acordo com a Lei, o Governo concede às comunidades ou aos indivíduos, um direito de uso e exploração da terra, ou Duat (Direito de Uso e Aproveitamento das Terras), para cultivar suas machambas, pequenos lotes agrícolas. Nas zonas rurais, porém, ninguém 
possuía o Duat, o documento, cuja importância era, às vezes subestimada pelos camponeses. Portanto, poderia acontecer da terra mudar de mãos insidiosamente.

A comunidade de Wuacua, em torno de 15 minutos da estrada de Nakarari, por sua vez, tinha muita consciência disso. Em 2012, funcionários do Distrito vieram pedir aos habitantes que assinassem documentos. Em troca, eles lhes prometeram uma soma de dinheiro e a realização de projetos sociais. Mas, tratava-se de outro propósito: a renúncia explícita ao Duat. Na verdade, os camponeses foram enganados, porquanto o objetivo dos funcionários era que eles participassem de um programa de desenvolvimento rural, solicitando que os referidos camponeses assinassem documentos que escapavam à compreensão dos mesmos.

Assim sendo, receberam uma recompensa entre 4.500 e 6.000 meticais (de $R \$ 265$ a 350), sendo forçados a se mudarem da área onde se encontravam. Posteriormente, a Agromoz, uma empresa de capital misto brasileira e portuguesa, obteve uma concessão de 9 mil hectares, nos quais passou a cultivar soja. A empresa valeu-se do fato da população em tela ser analfabeta e, não possuir muita clareza, a respeito do que estava acontecendo, porque havia problemas de comunicação relativos às línguas faladas.

Atualmente, Wuacua é um povoado fantasma, rodeado de plantações da Agromoz. Seguranças recrutados pela empresa não permitem que ninguém se aproxime desta área. A terra, nesta região, ainda está nua e prestes a ser semeada. Essa paisagem é muito diversa daquela que prevalece em Nakarari, na qual existem pequenas roças de feijão e mandioca e crescem mangueiras.

Convém ressaltarmos que, a Agromoz não tem relações com o projeto ProSavana, uma vez que a primeira, tem muito claro sobre o que promove. Portanto, em toda a região, a história de Wuacua e da expropriação das terras se espalhou por todos os arredores e, instruídos por essa experiência, os representantes dos camponeses começaram a desafiar o Governo. Apesar dos camponeses terem ouvido promessas dos funcionários do Governo, não as acataram, porque já estavam inteirados quanto à possibilidade de serem enganados. 0 Distrito de Mutuali tornou-se, desde então, o símbolo de uma contestação que, ao longo do tempo, ganhou todo o país, ultrapassando as fronteiras nacionais.

Além do que acima foi ressaltado, convém que lembremos que as organizações moçambicanas, ao inteirarem-se do que ocorrera em Mato Grosso, resolveram lograr conhecimentos, em torno da realidade brasileira, por iniciativa própria.

Em novembro de 2013, uma delegação moçambicana partiu para o interior do Brasil, retornando ao seu País com desagradável surpresa e decepção. 0 motivo que os deixou reservados estava relacionado com o que tinham visto no Brasil: centenas de quilômetros plantados com soja, não havendo nenhum camponês nesta extensa área e, nem sequer, uma comunidade rural. 0 território, também, estava completamente despojado de árvores, não havendo a presença de nenhuma forma de vida, porquanto a intensa utilização dos pesticidas e fertilizantes havia criado um deserto. 
De acordo com os moçambicanos que viram, de perto, a realidade acima exposta, a simples perspectiva que seu País sofresse o mesmo impacto, os deixou muito pouco propensos a integrar áreas de Moçambique, com um processo produtivo que lhes pareceu, totalmente, inadequado. Os moçambicanos salientaram que eles não eram contra o desenvolvimento, porém, achavam que os agricultores deveriam ser envolvidos e consultados, a respeito da implementação de processos produtivos que trouxessem vantagens às terras e à sociedade.

Alegaram os camponeses moçambicanos que o Governo arquitetou o plano sem os consultar. Em vez disso, o Governo estava pretendendo retirar as terras que eram por eles cultivadas há muitos anos. Segundo os camponeses moçambicanos, quando tiveram acesso ao Plano do Governo, deram-se conta que poderiam ser enganados.

Para agravar a situação, os camponeses tiveram conhecimento do conteúdo do documento elaborado pela GV Agro e, por dois escritórios do Japão (Oriental Consulting e NTC International), confirmando as preocupações presentes nas organizações camponesas. Através do aludido documento, foi explicitado o propósito de empurrar os agricultores das práticas tradicionais de cultivo e de gestão das terras, para práticas agrícolas intensivas, baseadas em sementes comerciais, insumos químicos e títulos fundiários privados.

Em face dos fatos explicitados, a mobilização camponesa logrou grande amplitude, com muita rapidez. No Brasil, no Japão e, em Moçambique, os movimentos camponeses e as associações compartilharam as informações e coordenaram suas ações. Vinte e três organizações moçambicanas escreveram uma carta aberta para os Governos japonês, brasileiro e moçambicano, na qual denunciaram a ausência total de um debate público amplo, transparente e democrático sobre uma questão de grande importância social, econômica e ambiental, que tinha impacto direto em suas vidas. Em seguida, cerca de quarenta organizações internacionais assinaram, também, a carta documento e a divulgaram.

Desta forma, as manifestações, as missões no exterior, a carta aberta, o movimento de opinião pública, unindo as organizações camponesas moçambicanas às do Brasil, endereçados aos universitários e às organizações da sociedade civil japonesa e europeia, tiveram o condão de fragilizar o Projeto.

Em Moçambique, o protesto alcançou todas as províncias do País, com a presença de caravanas organizadas para informar as comunidades, estimulando-as a não aceitarem propostas vazias, de funcionários. Portanto, o resultado foi muito significativo: pela primeira vez, o Governo moçambicano ouviu o povo, que lhe disse que não aceitaria um modelo de desenvolvimento imposto de cima para baixo.

Não resta dúvida de que, o que promovia o projeto de transformação do corredor de Nacala, em um novo Mato Grosso, começava a perder força. Por outro lado, preocupados com a possibilidade 
de não parecerem agentes de um novo colonialismo agrário, os japoneses foram os primeiros a levantar dúvidas sobre a sua pertinência. Os empresários brasileiros que visitaram o País, a convite da GV Agro, anunciaram que não estavam mais interessados e os técnicos da Agência Brasileira de Cooperação retornaram para o Brasil e, finalmente, o Fundo Nacala, foi fechado e o ProSavana suspenso.

Reconhecemos que é difícil quando se trata de movimentos sociais (os reivindicantes mais frágeis) levarem a melhor na luta que estabelecem. Todavia, no caso, aqui, exposto, felizmente podemos reconhecer a vitória clara dos camponeses moçambicanos.

\section{MOVIMENTO SOCIAL DOS NATIVOS DO ARQUIPÉLAGO DE CHAGOS (OCEANO ÍNDICO)}

Longe de qualquer outra terra emersa, as ilhas de coral de Chagos não escaparam aos conflitos do século XX. A instalação da base militar norte-americana em Diego Garcia provocou a deportação de todos os habitantes dessas ilhotas. Os nativos esperam, agora, que a Corte Internacional de Justiça reconheça seu direito de voltar e a soberania das Ilhas Maurício.

A mais de 1.500 quilômetros ao sul da Índia e, mais longe ainda de Seychelles ou das Ilhas Maurício, as 55 ilhotas de Chagos se espalham por mais de $250 \mathrm{~km}$ de comprimento, no meio do Oceano Índico. 0 conjunto dessas terras emersas forma uma superfície de $64 \mathrm{~km}^{2}$, não abrigando nenhum autóctone.

Seu destino, porém, interessou à Assembleia Geral das Nações Unidas, que decidiu, em junho de 2017, recorrer à Corte Internacional de Justiça para o julgamento da validade do desligamento desses territórios das Ilhas Maurício, quando a República obteve sua independência, em 1968.

Descoberto pelos portugueses em 1511, o arquipélago de Chagos, então desabitado, tornou-se depois holandês (1598-1710). Sob o domínio francês (1715-1814), os primeiros escravos africanos foram lá instalados, para trabalhar nas plantações de coco. O Reino Unido tomou posse do local em 1814, após as derrotas napoleônicas, tendo o controle do mesmo, até hoje, como Território Britânico do Oceano Índico.

O drama originado na descolonização incompleta do arquipélago se desenrolou em três atos: um acordo secreto com os EUA, uma divisão territorial e a deportação dos habitantes.

Para termos a compreensão da origem do problema que envolve o arquipélago de Chagos, devemos volver as nossas atenções para o período da Guerra Fria, que atribuía importância estratégica ao Oceano Índico.

Durante a Guerra do Vietnã, os EUA volveram suas atenções para a ilha de Diego Garcia (28 $\mathrm{km}^{2}$ ), cuja posição geográfica, ao sul do arquipélago de Chagos, permitia intervir em grande parte do globo e, policiar as grandes vias marítimas, pelas quais passavam combustíveis e matérias-primas. 
Os EUA, estabeleceram diálogos secretos com o Reino Unido, os quais terminaram em 1966, com uma troca de cartas com valor de Tratado, mas, sem exigir a aprovação do Parlamento britânico. Pelo Tratado, a Inglaterra colocou à disposição dos EUA, a ilha de Diego Garcia, por um prazo de cinquenta anos, conferindo papel de destaque a essa base aeronaval, sediada na ilha de mesmo nome, a qual entrou em operação em 1977.

Finda a Guerra Fria, novos objetivos militares e estratégicos fizeram de Diego Garcia um elo essencial do dispositivo norte-americano e, justificaram, de acordo com os militares, a tácita prorrogação do arrendamento por mais vinte anos.

A concessão de Diego Garcia precisava ser garantida por um Acordo com o novo Estado das Ilhas Maurício. Em virtude dos compromissos de Lancaster House, em setembro de 1965, os representantes mauricianos, cujo primeiro chefe de governo foi o trabalhista Seewoosagur Ramgoolam, tiveram de aceitar a perda de Chagos, em troca de uma compensação financeira, dos direitos de pesca e exploração de recursos marinhos do arquipélago, além da promessa de devolução do território, quando as instalações de defesa, ali existentes, não mais fossem necessárias.

As Ilhas Maurício obtiveram a independência em 12 de março de 1968, com um território que compreendia a ilha principal, as Ilhas Rodrigues, Saint-Brandon e Agaléga, mas, não Chagos, cujo estatuto jurídico se tornou complexo: o arquipélago continuou sob a soberania do Reino Unido, que concedeu direitos marítimos às Ilhas Maurício e, em terra, aos EUA.

Desde 1980, as Ilhas Maurício contestam o Acordo de Lancaster House, considerado injusto, segundo o princípio da intangibilidade das fronteiras herdadas da colonização. Elas receberam o apoio da Organização da Unidade Africana (OUA) e do Movimento dos Não Alinhados, notadamente, Índia e Sri Lanka, com o objetivo de fazer do Oceano Índico uma zona de paz, tendo em vista, a base de Diego Garcia.

Após dois séculos de imigração proveniente da França, África, Índia e Madagascar, os habitantes do arquipélago de Chagos formavam uma população singular, cerca de 2 mil pessoas, em três grupos de ilhas: Diego Garcia, Salomão e Peros Banhos. Entretanto, no curso de suas negociações com os britânicos, as autoridades norte-americanas insistiram na obtenção do controle exclusivo, sem os habitantes que, ali, estavam morando.

Os nativos, no seu falar crioulo, baseado no francês, denominaram-se ilois, tendo sido, aos poucos, expulsos do arquipélago, mediante a presença de três determinações: proibição de volta, após uma viagem; restrição da aquisição de alimentos e remédios e, envenenamento e sufocamento com gás, de todos os cães.

Em 1973, os últimos autóctones partiram exilados, em cargueiros, para Seychelles e Ilhas Maurício. Começavam assim, os tempos de miséria e sofrimento para esses deportados, que permaneceram párias nas terras de acolhida. 
A partir de 1990, começou a ser travado um demorado combate para contestar a legalidade da deportação, visando, também, o direito de regresso.

Londres, propôs então, uma indenização financeira aos nativos, todavia, aceitando esta compensação, os habitantes de Chagos comprometeram quaisquer ações judiciais futuras, como foi visto, através das rejeições de suas últimas demandas, perante a Corte Europeia dos Direitos Humanos, em 2012 e a Corte Suprema do Reino Unido, em junho de 2016.

Os processos movidos perante as jurisdições norte-americanas (a Corte do Distrito de Colúmbia e, como última instância, a Suprema Corte) para contestar a decisão de estabelecer a base militar em suas terras, também foram rejeitados, sob a alegação de que se tratava de um ato de governo não sujeito à justiça, em virtude da separação de poderes.

Assim, os nativos depositam as suas esperanças, atualmente, no reconhecimento da soberania das Ilhas Maurício sobre o arquipélago de Chagos.

A primeira oportunidade de resolver na justiça essa disputa se apresentou em 2010, após a decisão unilateral do Reino Unido, de criar uma "área marítima protegida", em volta do arquipélago de Chagos. Londres justificou a proibição de toda exploração de recursos vivos e minerais do arquipélago pelo cuidado em preservar o ambiente marinho. Mas, à luz de um telegrama diplomático, enviado pela embaixada dos EUA, em Londres e, revelado pelo WikiLeaks, essa decisão não parece ter sido motivada, unicamente, por considerações ecológicas. 0 documento cita palavras do diretor da Agência de Assuntos Estrangeiros e da Commonwealth, segundo as quais será difícil, se não impossível, aos antigos habitantes, realizarem sua volta às ilhas, caso o conjunto do arquipélago de Chagos se torne uma reserva marítima. Outra autoridade assegura aos norte-americanos, que esse estatuto não colocaria, em contrapartida, nenhum entrave às operações militares.

A decisão tinha por objetivo, na realidade, comprometer todo e qualquer projeto de reinstalação dos habitantes, privando-os de seu único meio de subsistência: a pesca. Todavia, as Ilhas Maurício contestaram a criação dessa área marítima protegida, perante o Tribunal Internacional do Direito Marítimo, ponderando que a iniciativa britânica lhes negaria os direitos concedidos para a exploração dos recursos de Chagos. A sentença arbitral de 18 de março de 2015 concluiu que o Reino Unido violou os Acordos de Lancaster House, com respeito às Ilhas Maurício e anulou a criação da área marítima protegida. Contudo, foi reconhecida uma assimetria nas relações dos três países envolvidos, evitando o tribunal em entrar, profundamente, na questão da soberania, bem como no reconhecimento das Ilhas Maurício, com o Estatuto de Estado Costeiro.

Diante dessa situação de bloqueio, as Ilhas Maurício decidiram internacionalizar a questão. Em 1965, a Assembleia Geral da ONU havia condenado a separação do arquipélago de Chagos e, pedido a Londres que não tomasse nenhuma medida destinada a desmembrar o território das Ilhas Maurício, violando sua integridade territorial. 
Em junho de 2017, ela decidiu por 94 votos a 15 e, com 65 abstenções, exigir um pedido de consulta à Corte Internacional de Justiça: um perigoso precedente, no dizer do representante do Reino Unido. A Corte deverá resolver se o processo de descolonização foi levado a bom termo, quando as Ilhas Maurício obtiveram sua independência, em 1968 e, esclarecer as consequências, em direito internacional, da permanência do arquipélago sob a administração do Reino Unido, notadamente no que diz respeito, à impossibilidade na qual se encontra Maurício de concretizar um programa de reinstalação para os seus nacionais.

A análise desse voto revelou o apoio, significativo, de grandes países do Sul (África do Sul, Arábia Saudita, Argélia, Argentina, Brasil, Cuba, Egito, Filipinas, Índia, Malásia, Nigéria, Paquistão e Vietnã). Era de se esperar a oposição à sentença, por parte dos aliados dos EUA e do Reino Unido (Afeganistão, Austrália, Coreia do Sul, Iraque, Israel e Japão) e, também, a França, que destacou a ilha de Maiote, da República de Comores. As abstenções da China e da Rússia talvez se expliquem pelas reservas desses países, em relação aos apelos à justiça internacional para dirimir conflitos territoriais, pois essas medidas poderiam lhes custar caro, nos casos da Crimeia e das ilhas do Mar da China.

Levando-se em conta as implicações geopolíticas e econômicas, a questão de Chagos ultrapassa o quadro bilateral anglo-mauriciano e seu desfecho é incerto. Na visão de Londres e Washington, Diego Garcia contribui para a segurança do planeta e, permite lutar contra as "ameaças híbridas" (terrorismo, pirataria, criminalidade transnacional) que poderiam afetar, sobretudo, o acesso ao Mar Vermelho e ao Golfo. Assim, esse caso parece sintomático da vontade dos Estados poderosos de fazerem prevalecer seus interesses militares e financeiros sobre os direitos humanos e dos povos.

\section{CONCLUSÕES}

A análise dos movimentos sociais explícitos neste trabalho, nos mostrou que as reivindicações e os protestos, dependendo de cada movimento, podem emergir, através de formas de expressão diferenciadas. Assim sendo, alguns aspectos relativos aos movimentos alvos da nossa discussão merecem um exame mais cuidadoso da nossa parte.

Quando nos debruçamos sobre o movimento dos Wampis, no Peru, teremos que ter em mente que as populações indígenas defendem sua autonomia, por meio da ideia de um Estado plurinacional. Portanto, a criação de um Governo Autônomo seria uma estratégia de defesa territorial, sendo uma resposta aos esforços feitos para a divisão dos Wampis, em comunidades. Todavia, essa proposta foi contrária à estrutura e aos objetivos do Governo peruano. Assim, a proposta dos Wampis referia-se a um Estado plurinacional, conforme, aliás, já estava registrado nas Constituições do Equador (2008) e da Bolívia (2009). 
Por outro lado, o Estado peruano é o condutor das políticas que abrangem todo o território do País, bem como as populações nele residentes, possibilitando ao Estado conceder parcelas a empresas extrativas, como as companhias petrolíferas, apesar dos riscos e, consequências de suas atividades para o ambiente e a saúde da população. Reforçando a ideia precedente, devemos ressaltar que o Estado peruano continua sendo o dono da água, da fauna e do subsolo, significando que o mesmo cede para uso o solo e os recursos florestais para as comunidades.

Depreendemos, então que, a criação das comunidades foi, em última instância, muito problemática porque, legalmente, os recursos continuam a pertencer ao Estado, que pode decidir explorar a floresta ou o petróleo, no interior dos territórios comunais, porque é responsável pelo desenvolvimento político e administrativo interno.

Pelo que precedentemente foi esclarecido, constatamos que há uma divergência fundamental entre a ideia da autonomia Wampis e a forma como o Estado peruano está, constitucionalmente, organizado. Por essa razão, consideramos que esse impasse tornará muito difícil a realização concreta do ideário assumido pelos Wampis.

No tange ao movimento social dos mineiros bolivianos, devemos observar algumas questões fundamentais.

Essa atividade mineral é realizada por cooperativas que dividem, entre si, os veios existentes nas maiores jazidas de metais preciosos da Bolívia. Segundo a Lei boliviana, as cooperativas são associações sem fins lucrativos, impulsionadas pelo trabalho solidário (Código das Cooperativas). Elas são um dos três atores envolvidos na produção mineral no País, ao lado da estatal Corporación Minera de Bolivia (Comibol) e de empresas privadas nacionais e transnacionais.

Em 2016, os cooperados mostraram uma nova lista de queixas. Além do cancelamento da modificação da Lei das Cooperativas, elas aventavam a possibilidade de se associarem as empresas privadas, a fim de que estas últimas, garantissem a exploração de suas concessões, bem como o relaxamento de normas ambientais que eram consideradas muito restritivas. Em face de tais acontecimentos, cinco Decretos, seguidos de Leis, fortaleceram o controle do Governo sobre as cooperativas.

Pelo visto, podemos perceber que a questão dos mineiros empregados e dos mineiros cooperados, não foi devidamente equacionada, também pelo fato de, à época, ter havido, no mercado internacional, o aumento dos preços das matérias-primas, o que motivou que, no âmbito do capitalismo neoliberal, as empresas levassem maior vantagem no processo da exploração mineral, na Bolívia, porquanto os mineiros já ressaltados, ficaram com os veios mais pobres que eram extraídos com equipamentos muito simples, em comparação com aqueles disponibilizados pela esfera empresarial. 
No que diz respeito ao movimento social dos camponeses moçambicanos, convém que salientemos que Nakarari, aldeia do Distrito de Mutuali, muito distante de Maputo, em Moçambique, apresentava moradores que discutiam o Projeto ProSavana, resolvendo dizer não ao advento do mesmo, em terras moçambicanas.

As organizações camponesas dos povoados vizinhos a esta aldeia, ponderaram que o Governo estava diante de um impasse, porquanto a luta de tais camponeses lograra obter uma primeira vitória histórica, impedindo a pilhagem das suas terras, com a reafirmação de que as mesmas, a eles pertenciam e eram por eles cultivadas há muito tempo.

Com uma superfície de 14 milhões de hectares, a zona pretendida pelo ProSavana, ao Norte de Moçambique, era considerada propícia às culturas de exportação (soja, algodão e milho), destinadas ao mercado mundial. Entretanto, o ProSavana reduzia a terra a um simples bem mercantil, não levando em conta sua importância para os pequenos produtores rurais.

Por trás da modernidade de uma cooperação Sul-Sul a serviço do desenvolvimento, o ProSavana alterava as relações de produção no campo, transformava os pequenos camponeses em trabalhadores, com contrato por tempo determinado ou indeterminado das grandes empresas e, pretendia fazer de Moçambique, uma plataforma central de produtos agroindustriais a serem exportados para o mundo inteiro.

Os camponeses de Moçambique ouviram falar, pela primeira vez do ProSavana, através de uma entrevista, então, concedida pelo ministro da Agricultura do seu País, a um jornal do Brasil. Tal fato preocupou os camponeses, uma vez que o Governo do seu País, até aquela data, não os havia informado a respeito do aludido Projeto.

O Distrito de Mutuali tornou-se, desde então, o símbolo de uma contestação que, ao longo do tempo, ganhou todo o país, ultrapassando as fronteiras nacionais.

Os moçambicanos salientaram que eles não eram contra o desenvolvimento, porém, achavam que os agricultores deveriam ser envolvidos e consultados, a respeito da implementação de processos produtivos que trouxessem vantagens às terras e à sociedade.

Em face dos fatos explicitados, a mobilização camponesa logrou grande amplitude, com muita rapidez. No Brasil, no Japão e, em Moçambique, os movimentos camponeses e as associações compartilharam as informações e coordenaram as suas ações. Vinte e três organizações moçambicanas escreveram uma Carta Aberta para os Governos japonês, brasileiro e moçambicano, na qual denunciaram a ausência total de um debate público amplo, transparente e democrático sobre uma questão de grande importância social, econômica e ambiental, que tinha impacto direto em suas vidas.

Desta forma, as manifestações, as missões no exterior, a Carta Aberta, o movimento de opinião pública, unindo as organizações camponesas moçambicanas às do Brasil, endereçados aos 
universitários e às organizações da sociedade civil japonesa e europeia, tiveram o condão de fragilizar o Projeto.

Reconhecemos que é difícil quando se trata de movimentos sociais (os reivindicantes mais frágeis) levarem a melhor na luta que estabelecem. Todavia, no caso, aqui, exposto, felizmente podemos assinalar a vitória clara dos camponeses moçambicanos.

Quanto à questão das populações nativas do Arquipélago de Chagos, algumas ponderações deverão ser feitas, à guisa de uma análise mais detida dos fatos.

A instalação da base militar norte-americana, em Diego Garcia, ilha sediada ao sul do arquipélago de Chagos, localizado no Oceano Índico, provocou a deportação de todos os habitantes dessas ilhotas. Os EUA volveram suas atenções para essa ilha, porque sua posição geográfica permitialhes intervir em grande parte do globo e, policiar as grandes vias marítimas, pelas quais passavam combustíveis e matérias-primas.

Os nativos deportados passaram a aguardar que a Corte Internacional de Justiça reconhecesse seu direito de retorno, bem como o advento da soberania das Ilhas Maurício, as quais, anteriormente, pertenciam ao arquipélago de Chagos.

Os habitantes do arquipélago procedentes da França, África, Índia e Madagascar formavam uma população singular, cerca de 2 mil pessoas, em três grupos de ilhas: Diego Garcia, Salomão e Peros Banhos.

Em 1973, os últimos autóctones partiram exilados, em cargueiros, para Seychelles e Ilhas Maurício. Começavam assim, os tempos de miséria e sofrimento para esses deportados, que permaneceram párias nas terras de acolhida.

A partir de 1990, começou a ser travado um demorado combate para contestar a legalidade da deportação, visando, também, o direito de regresso. Londres, que detinha a posse do território de Chagos, propôs então, uma indenização financeira aos nativos. Todavia, aceitando esta compensação, os habitantes de Chagos comprometeram quaisquer ações judiciais futuras, como foi visto, através das rejeições de suas últimas demandas, perante a Corte Europeia dos Direitos Humanos, em 2012 e a Corte Suprema do Reino Unido, em junho de 2016.

Assim, os nativos depositam, atualmente, as suas esperanças no reconhecimento da soberania das Ilhas Maurício, as quais o arquipélago de Chagos pertencia. Segundo eles, se essa situação se tornar realidade, talvez, eles poderão retornar ao arquipélago.

Devemos ressaltar que, até a atualidade, apesar dos esforços de instituições internacionais, entre elas, a ONU, o problema do retorno dos nativos ao arquipélago de Chagos, ainda, não logrou uma decisão que fosse favorável aos referidos.

Pelo que vimos, até o presente momento, não foram poucas as reivindicações levadas a termo pelos movimentos sociais, aqui analisados, visando salvaguardar os seus direitos à terra e à vida. 
Observamos que os protestos, por eles realizados, foram ora, através de canais legais e, através do diálogo, ora marcados por atitudes violentas com a consequente perda, até mesmo, de vidas humanas.

Enfim, ocorreram diálogos com os Estados nacionais, verificaram-se petições, junto às instituições internacionais, dotadas de caráter jurídico, ocorreram posturas adotadas por órgãos afetos aos direitos humanos, aos direitos indígenas e aos direitos dos povos que devem ter, legalmente, um chão para habitarem, viverem e se desenvolverem.

Infelizmente, não é menos verdade que, o capitalismo neoliberal, nos seus contornos presentes, as grandes empresas, profundamente ligadas à rentabilidade e à lucratividade do capital e os poderes constituídos dos Estados contemporâneos têm, sobremaneira, dificultado ao que chamaríamos o direito dos povos tradicionais de viverem em paz, com dignidade, bem como recursos para asseverarem a sua sobrevivência.

Finalmente, a pergunta que faremos, à guisa de conclusão é a seguinte: será que poderemos, ainda, com esperança, aguardarmos o advento de uma justiça, digna deste nome, que tenha condições de contemplar os anseios de toda a humanidade, independendo da classe social, a qual pertença o indivíduo ou grupos de indivíduos?

\section{REFERÊNCIAS}

CUBAS, T. E. A. Estudo da Contribuição da Imprensa na Representação dos Camponeses e Ruralistas no Pontal do Paranapanema, de 1998 a 2008. Universidade Estadual Paulista Júlio de Mesquita Filho. Presidente Prudente, 2009. 107 p. (Monografia em Geografia).

FERNANDES, B. M. Movimentos Socioterritoriais e Movimentos Socioespaciais: Contribuição Teórica para uma Leitura Geográfica dos Movimentos Sociais. Revista Nera. Presidente Prudente, v. 6, n. 8, p.24-34, 2005. Semestral. Disponível em: <http://revista.fct.unesp.br/index.php/nera/artic le/viewFile/1460/1436>. Acesso em: 19 nov. 2013.

. Sobre a Tipologia de Territórios. In: SAQUET, A. M.; SPOSITO, E. S. Territórios e Territorialidades: Teorias, Processos e Conflitos. p. 197-215. São Paulo: Expressão Popular, 2009.

PEDON, N. R. Movimentos Socioterritoriais: Uma Contribuição Conceitual à Pesquisa Geográfica. Universidade Estadual Paulista Júlio de Mesquita Filho. Presidente Prudente, 2009. 235 p. (Tese de Doutorado em Geografia).

SANTOS, M. A Natureza do Espaço. São Paulo: Edusp, 2008.

\section{BIBLIOGRAFIA CONSULTADA}

ANSEEUW, W.; WILY, L. A.; COTULA, L.; TAYLOR, M. Land Rights and the Rush for Land. Findings of the Global Commercial Pressures on Land Research Project [Direitos à terra e a corrida para obtê-la. Conclusões do projeto de pesquisa pressões comerciais mundiais sobre a terra]. Roma: International Land Coalition, 2012.

ARTIGO 41. Estabelece: O Território da Nação Wampis é Propriedade Coletiva e Ninguém Poderá Vendê-lo a Estrangeiros ou a Instituições Estatais ou Privadas.

BAXTER, J. Ruée sur les Terres Africaines [Corrida pelas terras africanas]. Le Monde Diplomatique, jan. 2010. Disponível em: <https://www.mondediplomatique.fr/2010/01/BAXTER/18713>.

BIAD, A.; EDYNAK, E. Chagos, Arquipélago Confiscado pelo Exército dos Estados Unidos. Le Monde Diplomatic Brasil. Ano 12 - Número 135. Outubro de 2018. São Paulo. p. 24-25, 2018. L'arbitrage Relatif à L'aire Marine Protégée des Chagos (Maurice C. Royaume-Uni) du 18 mars 2015: une décision prudente pour un litige complexe [A Arbitragem Relativa à Área Marítima 
Protegida de Chagos (Ilhas Maurício contra Reino Unido) de 18 de março de 2015: Uma Decisão Prudente para um Litígio Complexo]. Revue Québécoise de Droit International, n. 29. 1. Montreal, 2016.

BOCCARA, G. Le Gouvernement des "Autres". Sur le Multiculturalisme Néolibéral en Amérique Latine [O Governo dos "Outros". Sobre o Multiculturalismo Neoliberal na América Latina]. v.2, n. 50. Paris: Actuel Marx, 2011.

CABLE N. 001156 - From US Embassy, London, to US State Department [Telegrama n. 001156 - da Embaixada Norte-Americana, Londres, ao Departamento de Estado Norte-Americano]. The Guardian. 15 maio 2009.

CALIFICAN A PETROPERÚ COM 100\% DEL LOTE 192. [A Petroperú é Contemplada com $100 \%$ do Lote 192]. La República. Lima, 26 jan. 2018. Disponível

em:<https://larepublica.pe/economia/1176058califican-a-petroperu-con-el-100-del-lote-192>.

CHAPARRO, A. Estranhas Cooperativas Bolivianas. Le Monde Diplomatic Brasil. Ano 12 - Número 134. Setembro de 2018. São Paulo. p. 35, 2018.

. Duas Opções: A Direita ou a Direita. Le Monde Diplomatique Brasil, jun. 2016. Disponível em: $<$ https://diplomatique.org.br/duas-opcoes-direitaou-direita/>

COBAIN, I.; NORTON-TAYLOR, R. Claims of Secret CIA Jail for Terror Suspects on British Island to be Investigated [Exigência para que seja Investigada uma Prisão Secreta da CIA para Suspeitos de Terrorismo em Ilha Britânica]. The Guardian. Londres, 19 out. 2007.

CODJIA, P.; COLLIAUX, R. No Peru, os Wampis estão Determinados a Proteger seu Território. Le Monde Diplomatic Brasil. Ano 11 - Número 132. Julho de 2018. São Paulo. p. 14 a 16, 2018.

COLLIAUX, R. L'économiste, les Indigènes et le Cadastre [O economista, os nativos e o cadastro]. Le Monde Diplomatique, jun. 2016. Disponível em: http://www.bastamag.net/L-agriculture-bio-pournourrir-le-monde.

FACE OCULTA DO PROSAVANA. Youtube.com. 7 out. 2013. Disponível em: <https:// www.youtube.com/watch?v=jUKmyKf5E0k>.

FINER, M.; ORTA-MARTÍNEZ, M. Oil Frontiers and Indigenous Resistance in the Peruvian Amazon [Fronteiras Petrolíferas e Resistência Indígena na Amazônia Peruana]. Ecological Economics. v.70, n.2, Nova York, 15 dez. 2010.

GARRA, S.; GALA, R. R. Por el Curso de las Quebradas Hacia el "Territorio Integral Indígena": Autonomía, Frontera y Alianza entre los Awajún y Wampis [Ao Longo das Ravinas Rumo ao "Território Indígena Integral": Autonomia, Fronteira e Aliança entre os Awajún e os Wampis]. n.32. Lima: Anthropologica, 2014.
GRAIN.ORG. (Espanha). Leaked ProSavana Master Plan Confirms Worst Fears [Vazado, o Plano Básico do ProSavana Confirma Piores Medos], 30 abr. $2013 . \quad$ Disponível em: <https://www.grain.org/article/entries/4703leaked-prosavana-master-plan-confirms-worstfears>

Open Letter from Mozambican Civil Society Organisations and Movements to the Presidents of Mozambique and Brazil and the Prime Minister of Japan [Carta Aberta de Organizações e Movimentos da Sociedade Civil Moçambicana aos Presidentes de Moçambique e do Brasil e ao Primeiro-Ministro do Japão], 3 jun. 2013. Disponível em: https://www.grain.org/es/bulletin_board/entries/ 4738-open-letter-from-mozambican-civil-societyorganisations-and-movements-to-the-presidentsof-mozambique-and-brazil-and-the-primeminister-of-japan>

HONGO, J. ODA Transforming Mozambique [A ODA Contribui para a Transformação de Moçambique]. Japan Times. Tóquio, 6 jan. 2012. Disponível em: <https://www.japantimes.co.jp/news/2012/01/0 6/national/oda-transformingmozambique/\#.W_MQBOJReUk>.

LE GOUILL, C. La Politique Minière du Gouvernement d'Evo Morales: Entre Mythes et Pragmatisme Politique [A Política de Mineração do Governo de Evo Morales: Entre Mitos e Pragmatismo Político]. Paris: IdeAs, 2016.

LIBERTI, S. Camponeses Moçambicanos Derrotam o Agronegócio. Le Monde Diplomatic Brasil. Ano 11 Número 131. Junho de 2018. São Paulo. p. 11 a 13, 2018.

Main Basse sur la Terre. Land Grabbing et Nouveau Colonialisme [Expropriação da Terra. Apropriação de Grandes Extensões de Terra e Novo Colonialismo]. Paris: Rue de l'Échiquier, 2013.

MARIETTE, M. Em Busca da Pachamama. Le Monde Diplomatique Brasil mar. 2018. Disponível em: $<$ https://diplomatique.org.br/em-busca-dapachamama/>.

MELlO, P. C. Moçambique Oferece Terra à Soja Brasileira. Folha de S. Paulo, 14 ago. 2011.

MINISTÉRIO DE MINAS E DA METALURGIA. La Paz. 2015.

PENINOU, J. L. Un Redéploiement Stratégique dans la Corne de l'Afrique [Um Novo Posicionamento Estratégico no Chifre da África]. Le Monde Diplomatique. dez. 2001. Disponível em: <https://www.mondediplomatique.fr/2001/12/PENINOU/8241>.

PERU. Constituição del Peru. Sob a Presidência de Alberto Fujimori (1990-2000), a Constituição de 1993 Manteve Apenas uma "Imprescritibilidade" das Terras Comunais, o que Significa que elas Podem (sob certas condições) ser Vendidas, Cedidas, Doadas ou ainda Hipotecadas (art. 89). Disponível em: < 
http://www.oas.org/juridico/spanish/mesicic2_per_c onst_sp.pdf>.

RÉPUBLIQUE DÉMOCRATIQUE DU CONGO Acquisitions Foncières à Grande Échelle. Land Matrix. Disponível em: $<$ www.landmatrix.org/en/>.

RESOLUÇÃO № 71/292, de 22 de junho de 2017.

SCHUTTER, 0. de. How not to Think of LandGrabbing: Three Critiques of Large-Scale Investments in Farmland [Como não Pensar sobre a Questão da Apropriação de Grandes Extensões de Terra: Três Críticas a Investimentos de Grande Escala em Terras Cultiváveis]. The Journal of Peasant Studies. v.38, n.2, Abingdon (Reino Unido): Routledge, 2011.

SERVINDI.ORG - Comunicación Intercultural para un Mundo más Humano y Diverso - Pueblo Wampis Conforma Primer Gobierno Autónomo Indígena do Peru [0 Povo Wampis Confirma o Primeiro Governo Autônomo Indígena do Peru], Servindi, 30 nov. 2015. Disponível em: <www.servindi.org>.

SHANKLAND, A.; GONÇALVES, E. Imagining Agricultural Development in South-South Cooperation: The Contestation and Transformation of ProSavana [Pensando o Desenvolvimento Agrícola na Cooperação Sul-Sul: A Contestação e a Transformação do ProSavana]. v. 81. Amsterdã: World Development, 2016.
SURRALlED, A.; HIERRO P. G. Antropología de um Derecho. Libre Determinación Territorial de los Pueblos Indígenas como Derecho Humano [Antropologia de um Direito. Livre Determinação Territorial dos Povos Indígenas como Direito Humano]. Copenhague: IWGIA, 2009.

UNTC - United Nations Treaty Collection. Exchange of Notes Concerning the Availability for Defence Purposes of the British Indian Ocean territory [Troca de Notas sobre a Disponibilidade para Propósitos de Defesa do Território Britânico do Oceano Índico]. Londres, 30 dez. 1966. Disponível em:

https://treaties.un.org/doc/Publication/UNTS/Vo lume\%20603/volume-603-I-8737-English.pdf

VINE, D. The Truth about Diego Garcia [A Verdade sobre Diego Garcia]. Le Monde Diplomatique. Londres: Edição Inglesa, 2015.

Island of Shame: The Secret History of the US Military Base on Diego Garcia [Ilha da Vergonha: A História Secreta da Base Militar Norte-Americana em Diego Garcia]. Londres: Princeton University Press, 2009. 